\title{
Training Needs Assessment of Poultry Farmers in Imphal West and Imphal East of Manipur, India
}

\author{
Daya Ram*", M.K. Singh and J.M. Laishram \\ College of Agriculture, Central Agricultural University, Imphal-795004, Manipur, India \\ *Corresponding author
}

\section{A B S T R A C T}

\begin{abstract}
Keywords
Training needs, Feeding, Watering, Vaccination

Practices and

Scientific

Equipments practices.

Article Info

Accepted:

23 August 2017

Available Online:

10 September 2017

Commercial poultry farming has become one of the viable and proven enterprises all over the world due to its adaptability to varied agro-climatic conditions, low investment per unit, rapid growth rate and short generation interval. Since time immemorial poultry farming has played an important role to meet the domestic as well as socio-cultural needs of the rural people. The present study was conducted in Imphal East and Imphal West District of Manipur, Where were selected purposively on the poultry farmers rearing more than 200 birds' size and above. Fifty poultry farmers were selected randomly from each district totaling a size of 100 respondents. Total 100 respondents (Poultry farmers) were selected based on proportional random sampling method. The study concluded that majority of the farmers had medium training needs assessment on different aspects of poultry production practices. Age, Family size, Annual average income, Innovation proneness, Attitude toward poultry rearing, Utilization of mass media, Contact with extension staff and Marketing facilities were the important factors which have contributed to the training needs assessment by the poultry farmers.
\end{abstract}

\section{Introduction}

In developing countries, poultry represents an appropriate system to feed the fast growing human population and to provide income particularly to landless and small farmers, especially women. It makes one of the best uses of locally available resources. Although requiring low resource inputs and generally considered secondary to other agricultural activities by smallholder farmers, this type of production has an important contribution in supplying local populations with additional income and high quality protein. Poultry are also valued in religious and socio-cultural lives. However, high mortality, due to various diseases, constitutes one of the greatest constraints on poultry farming.
Other problems are related to breeding, feeding and marketing. Over the last decade, poultry population has grown spectacularly throughout the world, 23 per cent in developed and 76 per cent in developing countries, respectively. In India poultry farming under backyard system is as old as its civilization. Randhawa (1946) reported that numbers of terracotta have been discovered from Mohenjo-Daro and Harappa, which indicated that, the people domesticated number of birds and the domestic fowl (gallus gallus domesticus) originated in India and its ancestor's, the red jungle fowl (gallus gallus) is still found in northern India from Kashmir to Assam and in Madhya Pradesh, West 
Bengal, Orissa, Visakhapatnam and parts of Godavari district of Andhra Pradesh. He also reported that the Indus valley people kept the fowl only for sports, and that its breeding for flesh occurred later. Poultry production in India has increased six fold in ten years; it ranked $4^{\text {th }}$ in egg production and $18^{\text {th }}$ in broiler production in the world (Singh and Jilani, 2005). The contribution of poultry sector to India's GDP has remained below 1 per cent, but its share in the livestock sector is continuously rising. The government of India is well aware of the growth opportunities of the national poultry sector, and the eleventh five year plan 2007-2012 sets a target growth rate for the sector at 10 per cent per year, which is above the envisaged 9 per cent annual growth rate for total GDP (Anonymous, 2007). This achievement was due to tremendous efforts of research on housing, feeding, breeding, and disease prevention. According to the 2006 National Sample Survey's (NSS) "report on livestock ownership" (Anonymous, 2006), the landless, marginal and small scale farmers, which account for about 90 per cent of the 107 million agricultural households in India, keep about 85 per cent of the poultry stock of the country. While the production of agricultural crops has been rising at a rate of $1.5-2 \%$ per annum, eggs and broilers has been rising at a rate of $8-10 \%$ per annum (Mehta et al., 2003). National annual consumption is 37 billion eggs and one billion broilers. Estimates of income elasticity for meat and eggs strongly suggest that consumption of these products can be expected to continue to grow strongly. Per capita consumption of eggs in rural areas is less than half of the consumption in urban areas (Mehta et al., 2003). Among the north-eastern state of India, Manipur stands third in poultry production next to Assam and Tripura and in meat production it stands in fourth position. The total poultry population is 29.41 lakhs in 2003 as compared to 30.57 lakhs in
1997(Anonymous, 2007). But there have been increases from 22.28 tons in 2003-04 to 24.26 tons during 2008-09 (Anonymous, 2008-09). Poultry farming in the state were found to be one of the important sources of income, particularly for landless agricultural labourers. But poultry production under modern technologies needs high expenditure which is very difficult to adopt for the rural farmers of Manipur. Few resource rich farmers are involved in this venture. Some rural youths are also running their farm and earning a handsome amount with contractual basis and solely depend upon the resource rich farmer. Hence, another way to fulfil out the increasing demand of egg and chicken in state and to boost up the economic condition of the farmer is to adopt scientific poultry farming using locally available resources. Poultry farmers should essentially possess the scientific knowledge on farming to take preventive action, identify the disease condition, and various poultry management practices, etc. This knowledge could be acquired through experience or through contact with extension agencies and input suppliers. Knowledge is the totality of understanding of information possessed by a person. Knowledge is defined as those behaviour and test situation which emphasized the remembering either by recognition or recall of ideas, material or phenomenon (Bloom et al., 1956). Hence, a study was carried out to assess the commercial poultry farmers' knowledge on scientific poultry farming. It has been observed that considerable number of poultry farms has grown up in Imphal East and Imphal West District. Imphal being the main commercial centre of the state, availability of inputs like superior chicks, feeds, scientific equipments and labours has added momentum to the poultry business. Moreover veterinary services are also readily available with the establishment of veterinary hospital and private veterinary clinics in and around the 
Imphal city. Hence, there is a great scope for poultry rearing so as to fulfil the egg and meat requirement of the state and also to generate employment opportunities for unemployed youth in general and women section in particular. Thus, every effort should be made to utilize the proven poultry technology so as to increase the efficiency of poultry business in Manipur state. The present study was carried out with following specific objectives to study the personal, socio-economic and psychological characteristics of poultry farmers and analyze the training needs assessment of poultry farmers.

\section{Materials and Methods}

The present study was conducted in Imphal East and Imphal West District of Manipur, Where were selected purposively on the poultry farmers rearing more than 200 birds' size and above. Fifty poultry farmers were selected randomly from each district totaling a size of 100 respondents. Total 100 respondents (Poultry farmers) were selected based on proportional random sampling method. An interview schedule was prepared to collect information from the respondents. To check its validity the interview schedule was pre-tested on 10 poultry farmers (except sample) from Imphal East and Imphal West District. The schedule was finalized after making necessary amendments (by adding more demography parameters and erasing some doubted questions) in the light of pre testing experience. Training needs assessment of each specific area were assessed using a five point rating scale i.e. most needed, needed, somewhat needed, less needed and not needed and were qualified by assigning the scores as 5,4,3,2, and 1 respectively. The data thus collected were coded and fed to the computer for analysis. Statistical package for Social Sciences (SPSS) was used for analysis of the data and simple percentage, mean and standard deviations simple correlation coefficient and multiple regressions was counted.

\section{Results and Discussion}

The data presented in table 1 indicates that majority of the respondent belong to middle aged group $(57.00 \%)$ followed by young age group $(32.00 \%)$ and old categories $(11.00 \%)$. The result of the present study indicates that majority of the respondent belonged to middle age group. The possible reason for this would be that middle aged group usually engaged poultry rearing as a ready source of cash and learning experience. It was found that out of 100 respondents, 39 per cent were found to be from small size family which maintained nuclear norm, while $(61.00 \%)$ of the poultry farmers were from large size category maintaining joint family norm. Table 1 shows that $(33.00 \%)$ of the poultry farmers studied up to middle school, followed by $(28.00 \%)$ up to high school, $(22.00 \%)$ up to graduate and above, (4.00\%) up to primary school, and $(5.00 \%)$ belongs to read and write category whereas, 6.00 per cent are in illiterate category. Majority $(77.00 \%)$ of the respondents fell in the category of low income group, earning annual average income below Rs.50,000; followed by $(20.00 \%)$ in medium category earning between Rs.50,000 to Rs.1,00,000; and (3.00\%) with high income category above Rs. 1,00,000. The possible reason for this could be that lack of income source from land and unemployment.

Table 1 reveals that majority $(60.00 \%)$ of the respondents fell in the category of medium group, followed by $(27.00 \%)$ in high category and $(13.00 \%)$ of the respondents belonged to low socio-economic status. Majority $(52.00 \%)$ of the respondents was found to own medium flock size holding, followed by $(38.00 \%)$ with a large flock size and, only $(10.00 \%)$ poultry owners had a small flock size. It was evident from the result, that 
majority (44.00 per cent) of the respondent had high access of innovation proneness followed by (30.00\%) having low access and, $(26.00 \%)$ with medium access to innovation proneness.

Table 1 results revealed that majority $(41.00 \%)$ of the respondents' possessed favourable attitude towards poultry farming followed by $(38.00 \%)$ which might be due to the fact that the respondents were convinced with the benefits reaped from the poultry rearing. However, only $(21.00 \%)$ of the respondents do not expressed apprehension on its advantages. Majority (63.00\%) of the respondents were in category of medium level of economic motivation which is followed by high $(21.00 \%)$ and, $(16.00 \%)$ with the low level of economic motivation category.

The table 1 indicates that majority 59.00 per cent of the respondents were having medium utilization of the information on poultry farming, followed by $(23.00 \%)$ with high utilization, and only (18.00\%) have low utilization of information. It was found that $(59.00 \%)$ of the respondents had medium contact with extension staff, followed by 22.00 per cent with low contact and, only 19.00 per cent of the respondents have high contact. Majority (43.00 \%) of the respondents was having medium marketing facilities followed by 35.00 per cent with high facilities and only 22.00 per cent were having low marketing facilities.

\section{Training needs assessment in housing practices}

There is evident from table 2 that on the basis of mean scores and the extent of important training need against each component of poultry farming. The results explicate that the respondent perceived most important training need in the area of housing practices with mean score of ventilation system (3.36) followed by Roof management system (3.33), lighting system (3.27) and in housing practices shed sanitization had a mean score (3.00).

\section{Training needs assessment of in brooding} of chicks

It is evident from table 2 indicate the mean training need scores and the extent of importance of training need against each component of poultry farming. The results revealed that the respondents perceived most important training needs in the area of brooding, proper lighting system had a mean score of 2.84 followed by brooding period (2.71), scientific methods (2.33) and traditional methods (2.2).

Table.1 To study the personal, socio-economic and psychological characteristics of poultry farmers

\begin{tabular}{|l|l|l|l|l|}
\hline S. No. & \multicolumn{1}{|c|}{ Category } & Frequency & Percentage & $\begin{array}{l}\text { Mean Score \& } \\
\text { Standard } \\
\text { Deviation }\end{array}$ \\
\cline { 1 - 4 } 1. & \multicolumn{4}{|c|}{ Age } \\
\hline & Young(25-40 Years) & 32 & 32.00 & 1.79 \\
\hline & Middle(40-50 Years) & 57 & 57.00 & \\
\hline & Old(50Year Above) & \multicolumn{2}{|c|}{ Family size } \\
\cline { 1 - 4 } & \multicolumn{5}{|c|}{11.00} & \\
\hline & Small size (below 5 member) & 39 & 39.00 & 1.61 \\
\hline & Large size (5 member and above) & 61 & 61.00 & \\
\hline
\end{tabular}




\begin{tabular}{|c|c|c|c|c|}
\hline 3. & \multicolumn{4}{|c|}{ Educational Status } \\
\hline & Illiterate & 6 & 6.00 & \\
\hline & Can read only & 2 & 2.00 & \\
\hline & Can read and write only & 5 & 5.00 & \\
\hline & Primary & 4 & 4.00 & \\
\hline & Middle school & 33 & 33.00 & \\
\hline & High school & 28 & 28.00 & \\
\hline & Graduate & 22 & 22.00 & \\
\hline 4. & \multicolumn{4}{|c|}{ Annual Average Income } \\
\hline & Low (Below Rs.50,000) & 77 & 77.00 & \multirow{3}{*}{1.26} \\
\hline & Medium (Rs.50,000-1,00,000) & 20 & 20.00 & \\
\hline & High (Above Rs.1,00,000) & 3 & 3.00 & \\
\hline 5. & \multicolumn{4}{|c|}{ Socio-economic status } \\
\hline & Low (Mean-SD) & 13 & 13.00 & \multirow{3}{*}{$\begin{array}{l}\mathrm{M}=23.28 \text { S.D.= } \\
3.64\end{array}$} \\
\hline & Medium(Mean_+SD) & 60 & 60.00 & \\
\hline & High (Mean+SD) & 27 & 27.00 & \\
\hline 6. & \multicolumn{4}{|c|}{ Flock size(no. of birds) } \\
\hline & Small(50-250) & 10 & 10.00 & \multirow{3}{*}{$\begin{array}{l}\text { Mean }=2.28 \\
\text { S.D. }=0.63\end{array}$} \\
\hline & Medium(251-500) & 52 & 52.00 & \\
\hline & Large(above 501) & 38 & 38.00 & \\
\hline 7. & \multicolumn{4}{|c|}{ Innovation proneness } \\
\hline & Low (Mean-SD) & 30 & 30.00 & \multirow{3}{*}{$\begin{array}{l}\text { Mean }=5.59 \\
\text { S.D. }=1.56\end{array}$} \\
\hline & Medium(Mean_+SD) & 26 & 26.00 & \\
\hline & High (Mean+SD) & 44 & 44.00 & \\
\hline 8. & \multicolumn{4}{|c|}{ Attitude toward poultry rearing } \\
\hline & Low (Mean-SD) & 21 & 21.00 & \multirow{3}{*}{$\begin{array}{l}\text { Mean }=24.71 \\
\text { S.D. }=2.60\end{array}$} \\
\hline & Medium(Mean_+SD) & 41 & 41.00 & \\
\hline & High (Mean+SD) & 38 & 38.00 & \\
\hline 9. & \multicolumn{4}{|c|}{ Economic motivation } \\
\hline & Low (Mean-SD) & 16 & 16.00 & \multirow{3}{*}{$\begin{array}{l}\text { Mean }=14.30 \\
\text { S.D. }=2.50\end{array}$} \\
\hline & Medium(Mean_+SD) & 63 & 63.00 & \\
\hline & High (Mean+SD) & 21 & 21.00 & \\
\hline 10. & \multicolumn{4}{|c|}{ Utilization of Mass Media } \\
\hline & Low (Mean-SD) & 18 & 18.00 & \multirow{3}{*}{$\begin{array}{l}\text { Mean }=9.90 \\
\text { S.D. }=2.54\end{array}$} \\
\hline & Medium(Mean_+SD) & 59 & 59.00 & \\
\hline & High (Mean+SD) & 23 & 23.00 & \\
\hline 11. & \multicolumn{4}{|c|}{ Contact with extension staff } \\
\hline & Low (Mean-SD) & 22 & 22.00 & \multirow{3}{*}{$\begin{array}{l}\text { Mean }=5.79 \\
\text { S.D. }=3.55\end{array}$} \\
\hline & Medium(Mean_+SD) & 59 & 59.00 & \\
\hline & High (Mean+SD) & 19 & 19.00 & \\
\hline 12 & \multicolumn{4}{|c|}{ Marketing facility } \\
\hline & Low (Mean-SD) & 22 & 22.00 & \multirow{3}{*}{$\begin{array}{l}\text { Mean }=8.37 \\
\text { S.D. }=1.20\end{array}$} \\
\hline & Medium(Mean_+SD) & 43 & 43.00 & \\
\hline & High (Mean+SD) & 35 & 35.00 & \\
\hline
\end{tabular}


Table.2 To analyze the training needs assessment of poultry farming

\begin{tabular}{|c|c|c|c|c|c|c|c|c|c|}
\hline \multirow{2}{*}{$\begin{array}{l}\text { S } \\
\text { No. }\end{array}$} & \multirow[b]{2}{*}{$\begin{array}{l}\text { Training Needs } \\
\text { Assessment of } \\
\text { Poultry Farming }\end{array}$} & \multicolumn{5}{|c|}{ Degree of Training needs } & \multirow[b]{2}{*}{$\begin{array}{c}\text { Total } \\
\text { obtained } \\
\text { score }\end{array}$} & \multirow[b]{2}{*}{$\begin{array}{l}\text { Mean } \\
\text { Score }\end{array}$} & \multirow[b]{2}{*}{$\begin{array}{c}\operatorname{Ran} \\
\mathbf{k}\end{array}$} \\
\hline & & $\begin{array}{c}\text { Most } \\
\text { needed } \\
(5)\end{array}$ & $\begin{array}{l}\text { Needed } \\
\text { (4) }\end{array}$ & $\begin{array}{c}\text { Somewhat } \\
\text { needed } \\
\text { (3) }\end{array}$ & $\begin{array}{c}\text { Less } \\
\text { needed } \\
(2)\end{array}$ & $\begin{array}{c}\text { Not } \\
\text { needed } \\
(1)\end{array}$ & & & \\
\hline 1. & \multicolumn{9}{|c|}{ Housing Practices } \\
\hline i) & Shed Sanitization & 14 & 31 & 19 & 13 & 23 & 300 & 3.00 & IV \\
\hline ii) & Lighting System & 11 & 42 & 22 & 13 & 12 & 327 & 3.27 & III \\
\hline iii) & $\begin{array}{l}\text { Roof Management } \\
\text { System }\end{array}$ & 16 & 38 & 20 & 15 & 11 & 333 & 3.33 & II \\
\hline iv) & $\begin{array}{l}\text { Ventilation } \\
\text { System }\end{array}$ & 16 & 38 & 22 & 14 & 10 & 336 & 3.61 & I \\
\hline 2. & \multicolumn{9}{|c|}{ Training need in Brooding of chicks } \\
\hline i) & $\begin{array}{l}\text { Traditional } \\
\text { methods }\end{array}$ & 4 & 19 & 10 & 27 & 40 & 220 & 2.20 & IV \\
\hline ii) & Scientific methods & 13 & 11 & 12 & 24 & 40 & 233 & 2.33 & III \\
\hline iii) & $\begin{array}{l}\text { Proper lighting } \\
\text { system }\end{array}$ & 14 & 27 & 12 & 22 & 26 & 284 & 2.84 & I \\
\hline iv) & Brooding period & 9 & 29 & 14 & 20 & 28 & 271 & 2.71 & II \\
\hline 3. & \multicolumn{9}{|c|}{ Training need in Feeding of Balanced ration } \\
\hline i) & $\begin{array}{l}\text { Locally processed } \\
\text { feed }\end{array}$ & 19 & 18 & 17 & 1 & 45 & 265 & 2.65 & IV \\
\hline ii) & Branded feed & 16 & 41 & 24 & 10 & 9 & 345 & 3.45 & I \\
\hline iii) & Feeding period & 17 & 42 & 20 & 12 & 9 & 342 & 3.42 & II \\
\hline iv) & Feeding pattern & 13 & 45 & 21 & 11 & 10 & 340 & 3.40 & III \\
\hline 4. & \multicolumn{9}{|c|}{ Training need in Debeaking } \\
\hline i) & $\begin{array}{l}\text { Locally available } \\
\text { machinenary }\end{array}$ & 4 & 6 & 3 & 7 & 80 & 147 & 1.47 & III \\
\hline ii) & $\begin{array}{l}\text { Scientific } \\
\text { equipments }\end{array}$ & 5 & 7 & 6 & 4 & 78 & 157 & 1.57 & II \\
\hline iii) & Age of Debeaking & 7 & 6 & 8 & 4 & 75 & 160 & 1.60 & I \\
\hline 5. & \multicolumn{9}{|c|}{ Training need in Deworming } \\
\hline i) & Deworming period & 2 & 7 & 9 & 5 & 77 & 152 & 1.52 & III \\
\hline ii) & $\begin{array}{l}\text { Days of } \\
\text { Deworming }\end{array}$ & 4 & 8 & 6 & 3 & 79 & 155 & 1.55 & II \\
\hline iii) & \begin{tabular}{|l} 
Care after \\
Deworming and \\
Management
\end{tabular} & 9 & 7 & 8 & 4 & 72 & 177 & 1.77 & $\mathrm{I}$ \\
\hline 6. & \multicolumn{9}{|c|}{ Training need in Vaccination } \\
\hline i) & \begin{tabular}{|l|} 
Vaccination \\
period
\end{tabular} & 25 & 52 & 11 & 4 & 8 & 382 & 3.82 & I \\
\hline ii) & Vaccine handling & 23 & 53 & 12 & 3 & 9 & 378 & 3.78 & IV \\
\hline iii) & $\begin{array}{l}\text { Procurement } \\
\text { before vaccination }\end{array}$ & 22 & 54 & 13 & 4 & 7 & 380 & 3.80 & II \\
\hline iv) & \begin{tabular}{|l} 
Care after \\
vaccination and \\
Management
\end{tabular} & 23 & 52 & 13 & 5 & 7 & 379 & 3.79 & III \\
\hline
\end{tabular}


Table.3 Correlation coefficient of selected independent variables (x) and with the dependent variable (y) (Training needs assessment of poultry farmers)

\begin{tabular}{|c|l|c|}
\hline Sl. No. & \multicolumn{1}{|c|}{ Independent variable } & 'r' \\
\hline $\mathrm{X} 1$ & Age & $.248^{*}$ \\
\hline $\mathrm{X} 2$ & Family size & $-.204^{*}$ \\
\hline $\mathrm{X} 3$ & Educational status & $-.132 \mathrm{NS}$ \\
\hline $\mathrm{X} 4$ & Annual average income & $.738^{* *}$ \\
\hline $\mathrm{X} 5$ & Socio-economic status & $-.067 \mathrm{NS}$ \\
\hline $\mathrm{X} 6$ & Flock size (no. of poultry birds) & $.163 \mathrm{NS}$ \\
\hline $\mathrm{X} 7$ & Innovation proneness & $-.364^{* *}$ \\
\hline $\mathrm{X} 8$ & Attitude toward poultry rearing & $-.566^{* *}$ \\
\hline $\mathrm{X} 9$ & Economic motivation & $.139 \mathrm{NS}$ \\
\hline $\mathrm{X} 10$ & Utilization of mass media & $.547^{* *}$ \\
\hline $\mathrm{X} 11$ & Contact with extension staff & $.606^{* *}$ \\
\hline $\mathrm{X} 12$ & Marketing facilities & $.591^{* *}$ \\
\hline $\mathrm{X} 13$ & Supervision of poultry farm & $-.099 \mathrm{NS}$ \\
\hline
\end{tabular}

** Significant at the 0.01 level * Significant at the 0.05 level NS= Non Significant

Table.4 Regression analysis of independent variables (x) with the dependent variable (y)

\begin{tabular}{|r|l|r|r|r|}
\hline S. No. & \multicolumn{1}{|c|}{ independent variable } & $\begin{array}{c}\text { Regression Co- } \\
\text { efficient 'b' }\end{array}$ & $\begin{array}{c}\text { Standard } \\
\text { error (S.E) }\end{array}$ & 't' value \\
\hline X1 & Age & .091 & 2.248 & 1.304 \\
\hline X2 & Family size & -.047 & 2.899 & -.662 \\
\hline X3 & Educational status & .060 & 1.679 & .910 \\
\hline X4 & Annual average income & .312 & 4.453 & $2.799 * *$ \\
\hline X5 & Socio-economic status & -.060 & .200 & -.934 \\
\hline X6 & Flock size (no. of poultry birds) & .131 & 2.130 & 1.944 \\
\hline X7 & Innovation proneness & -.026 & .984 & -.336 \\
\hline X8 & Attitude toward poultry rearing & -.198 & .639 & -2.405 \\
\hline X9 & Economic motivation & -.117 & .538 & -1.571 \\
\hline X10 & Utilization of mass media & .130 & .660 & 1.568 \\
\hline X11 & Contact with extension staff & .186 & .543 & $1.939 *$ \\
\hline X12 & Marketing facilities & .199 & 1.536 & $2.171 * *$ \\
\hline X13 & Supervision of poultry farm & .051 & .650 & .730 \\
\hline
\end{tabular}

* Significant at the $0.05<\mathrm{p}, \mathrm{R}^{2}=0.681, \mathrm{~F}=14.111 *$

** Significant at the $0.01<\mathrm{p}, \mathrm{NS}=$ Non significant

Training need assessment in feeding of Balanced ration

It was found that table 2 indicate that on the basis training need mean score the feeding of balanced ration such as branded feed (3.45) followed by feeding period (3.42), feeding pattern (3.40) and locally processed feed
(2.65) were rated as more required training need.

\section{Training needs assessment in debeaking}

A perusal of data presented in table 2 reveals that on the basis of mean score, the debeaking such as age of debeaking (1.60) followed by 
scientific equipments (1.57) and locally available machinery (1.47) were rated as more required training needs.

\section{Training need assessment in deworming}

The result in table 2 explicate that the respondents perceived most important training need in care after deworming and management with mean score (1.77) followed by days of deworming and deworming period with the mean score 1.55 and 1.52 respectively.

\section{Training need assessment in vaccination}

It is evident from table 2 that on the basis of mean score, the vaccination such as vaccination period (3.82) followed by procurement before vaccination (3.80), care after vaccination and management (3.79) and vaccine handling (3.78) were rated as more required training needs.

This section deals with the nature of relationship between selected dependent variables and independent variables. For ascertaining the relationship correlation coefficient was calculated between dependent variable and the thirteen independent variables separately for Training needs assessment of poultry farmers. Correlation coefficients between Age, Family size, Annual average income, Innovation proneness, Attitude toward poultry rearing, Utilization of mass media, Contact with extension staff and Marketing facilities were found highly positive and significant of personal, psychological, socio-economic and communication characteristics with Training needs assessment of poultry farmers. (Thammi et al., 2007), (Saha et al., 2010), (Bhushan et al., 2012), (Ezeh et al., 2012), (Oyeyinka et al., 2011) and (Senthilkumar et al., 2009) (Table 3). Whereas Educational status, Socio-economic status, Flock size (no. of poultry birds), Economic motivation and Supervision of poultry farm was found to be negative significance of personal, psychological, socio-economic \& communication characteristics with Training needs assessment of poultry farmers.

The determinants of Training needs Assessment of the poultry farmers in Imphal West and Imphal East District of Manipur production are presented in table 4 the result of the analysis indicated that out of total 13 independent variables only four of them i.e. annual average income, attitude towards poultry rearing, contact with extension staff and marketing facilities were found to be significant at 0.01 and 0.05 level of significant respectively. The estimated coefficient for annual average income, Contact with extension staff and Marketing facilities were found positive and has ' $t$ ' value (2.799), (1.939) and (2.171) respectively that implies Training has positive impact on each variables, every one per cent increase in training would lead to 31.2 per cent increase in income (Ezeh et al., 2012; Effiong, 2005). Attitude towards poultry rearing has negative coefficient of (-0.198) and has ' $t$ ' value (2.405) which indicated that increase in attitude toward poultry rearing reduces the level of training need assessment to the poultry farmer. The $\mathrm{R}^{2}$ value $(0.681)$ indicated that 68.1 per cent was contributed towards the training need due to independent variables. These four variables (i.e. annual average income, attitude towards poultry rearing, contact with extension staff and marketing facilities) could be term as good predictor of training need assessment of the poultry farmers.

\section{Acknowledgment}

The authors acknowledge the contributions of, Daya Ram, M.K. Singh and J.M. Laishram College of Agriculture, Central Agricultural 
University, Imphal, Manipur for their technical and financial support to project and valuable contributions to the manuscript.

\section{References}

Anonymous, 2006. Livestock Ownership across Operational Land Holding Classes in India. NSS 59th round, report no. 493 (59/18.1/1), Government of India, New Delhi.

Anonymous, 2007. Directorate of Veterinary and Animal Husbandry Services, Government of Manipur. Unpublished $18^{\text {th }}$ Quinquennial Livestock Census, 2007.

Anonymous, 2007. Eleventh five year plan (2007-2012). Planning Commission, Government of India, New Delhi.

Anonymous, 2008. Directorate of Economics and Statistics, Government of Manipur. Economic Survey of Manipur.

Bhushan Bharat, Malik, J.S., Narwal, R.S. and Rakesh Sharma. 2012. Factors Responsible for the Adoption of Scientific Technological Practices (STPs) Indian Journal of Agricultural Research. 44 (4): 306 - 310

Bloom, B.S., Engelhardt, M., Furnst, E., Hill, W. and Krathwal, D.R. 1956. Taxonomy of Educational Objectives The Cognitive Domain. Longmans Green, New York.

Dessie, T., and Ogle, B. 1996. Studies on poultry production systems in the Central Highlands of Ethiopia. Swedish University of Agricultural Sciences, M.Sc. Thesis, Department of Animal Nutrition and Management.

Effiong, E. O., 2005. Efficiency of production in selected livestock Enterprises in Akwa-Ibom State, Nigeria. Ph.D. Thesis, Dept. of Agricultural Economics, Michael Okpara University of Agriculture, Umudike.

Ezeh, C. I., Anyiro, C.O. and Chukwu, J. A.
2012. Technical Efficiency in Poultry Broiler Production in Umuahia Capital Territory of Abia State, Nigeria. Greener Journal of Agricultural Sciences. 2 (1), pp. 001-007.

FAO, 2007. Poultry as a Tool in Human Development, Paper Prepared for FAO, Rome.

Holloway, G., and Ehui, S. 2002. Expanding Market Participation among Smallholder Livestock Producers. A Collection of Studies Employing Gibbs Sampling and Data from the Ethiopian Highlands, 1998- 2001. SocioEconomics and Policy Research Working Paper 48. ILRI (International Livestock Research Institute), Nairobi, Kenya.pp. 85.

Mehta, R., Nambiar, R.G., Delgado, C. and Subramanian, S. (2003). Annex II: Livestock Industrialization Project: Phase II - Policy, Technical, and Environmental Determinants and Implications of the Scaling-up of Broiler and Egg Production in India. IFPRI-FAO Project on Livestock Industrialization, Trade and SocialHealth-Environment Impacts in Developing Countries.

National Commission on Agriculture 1976. Report Government of India. Ministry of Agriculture and Irrigation, New Delhi, Part VII (Animal Husbandry).

Oyeyinka, R. A., Raheem, W. K., Ayanda, I. F. and Abiona, B. G. 2011. Poultry Farmers' Awareness and Knowledge of Improved Production Practices in Afijio, Local Government Area, Oyo State, Nigeria. E3 Journal of Agricultural Research and Development. 1 (1):001-008.

Randhawa, M. S. 1946. Role of Domesticated Animals in Indian History. Science and Culture. XII (1).

Saha, Debasish, A.K., and, H. A, and Hai, A. 2010. Livestock farmers' knowledge 
about rearing practices in Ganderbal of Jammu and Kashmir. Indian Research Journal of Extension Education.10 (2): 15-17.

Senthilkumar, R., Nita, Khandekar and Narmatha, N. 2009. Knowledge Level among Poultry Entrepreneurs on Scientific Layer Farming. Tamilnadu Journal of Veterinary and Animal Sciences. 5 (3): 94-98.

Singh, C. B., and Jilani, M. H. 2005. Backyard Poultry Farming in Garhwal Himalayas. Indian Journal of Poultry Sciences. 40 (2): 195-198.

Singh, D. P., 2000. Thrills and Challenges for Backyard Poultry Production. In: Proceedings of Recent Advances in
Rural Poultry Farming, CARI, Izatnagar.

Singh, Khajan 2006. Differential Correlates of Dairy Beneficiaries under Integrated Rural Development Programme in Hill and Plain Areas. Indian Journal of Extension Science.1 (1): 68-71.

Thammi Raju, D., Sudhakar Rao, B. and Ramesh Gupta, B. 2007. Knowledge Level of Commercial Poultry Farmers. Indian Journal of Animal Research. 41 (1): $51-54$.

Yhome, E., Sapcota, D. and. Saharia, K.K. 2011. Poultry Farmers of Kohima and Dimapur Districts of Nagaland. Tamilnadu Journal Veterinary and Animal Sciences. 7(3):210-212.

\section{How to cite this article:}

Daya Ram, M.K. Singh and Laishram, J.M. 2017. Training Needs Assessment of Poultry Farmers in Imphal West and Imphal East of Manipur. Int.J.Curr.Microbiol.App.Sci. 6(9): 22182227. doi: https://doi.org/10.20546/ijcmas.2017.609.272 